\title{
LEXICAL AND GRAMMAR COHESION IN THE COLLECTION OF "MUSEUM PENGHANCUR DOKUMEN" POETRY BY AFRIZAL MALNA
}

\author{
Marlina Agkris Tambunan ${ }^{1}$ \\ Universitas HKBP Nommensen Pematangsiantar
}

\begin{abstract}
The purpose of this study is to describe the elements of lexical cohesion and grammatical cohesion elements in the poem discourse "Museum of Destruction of Documents" by Afrizal Malna. This research uses descriptive qualitative method by using library, reading, and note taking techniques. Data analysis was performed by data reduction, data presentation, then described and verified. Based on the research findings, it was concluded that the grammatical cohesion used in the collection of poetry "Museum Destroyer Documents" by Afrizal Malna found as many as 313 markers which include; 1) referencing 168 markers; 2) absorption of 2 markers; and 3) assembling 143 markers. Furthermore, the use of lexical cohesion used in the discourse on the poem "Document Shredder" by Afrizal Malna was found as many as 93 markers which included; 1) repetition of 39 markers; 2) synonym 11 markers; 3) antonimi 29 markers; 4) collocation of 9 markers; and 5) equivalence of 5 markers. When combined, the total usage of both is 406 markers.
\end{abstract}

Keywords: lexical cohesion, grammatical cohesion, poetry

\section{INTRODUCTION}

One of the elements forming discourse is cohesion. Cohesion is a form relationship that binds the linguistic elements to a discourse. This statement is in line with the statement of Nunan (1993: 21) which states that cohesion shows the fabric of utterances in sentence form so that there is unity and attachment in it. This means that the relationship of meaning, both lexical meaning and grammatical meaning, needs to be realized in an integrated manner in the unity that forms the text. So the sentences that are built in the discourse must be good and complete in order to obtain a good and complete discourse as well. Only with such a cohesive relationship can an element of a discourse be interpreted, in accordance with the dependence of other elements.

Furthermore, the elements in a discourse have formal lingual markers. Cohesion markers consist of two parts, namely grammatical cohesion and lexical cohesion. Grammatical cohesion is the relationship between one element with another element so as to build a unified text, while lexical cohesion is a relationship between elements in discourse semantically (Antony et al, 2012: 372). Cohesion can be divided into referencing, substitution, ellipsis and conjunction and lexical cohesion (Halliday and Hasan, in Nunan, 1993: 21).

Reference or reference is grammatical cohesion in the form of certain lingual units that refer to units other linguals that precede or follow it. Setiawan (2010: 57) provides a reference or reference as a form of discourse whose interpretation is not obtained from semantic relations, but from things outside of semantics. Types of reference can be divided into three types. First, reference to persona, which can be observed through personal pronouns which include first person, second person, and third person, both singular 
and plural. Sumarlam (2003: 24) mentions the three personas above can be divided into free and bound forms. The free form can stand alone, while the bound form can be attached to the left and there is attached to the right.

Second, demonstrative reference, which is divided into two, namely temporal demonstrative pronouns and locational demonstrative pronouns. Temporal demonstrative pronouns relate to time, and locational demonstrative pronouns relate to place. And finally, third, comparative reference, which is one of the grammatical cohesion that compares two or more things that have similarities or similarities in terms of form, attitude, nature, character, behavior and so on.

Furthermore, recovery or substitution is the replacement of certain lingual units with other lingual units in the form of words or phrases. In terms of lingual units, substitution can be divided into nominal (noun), verbal, frasal, and clause substitution (Nugroho, 2012: 3). Impulse or ellipsis is a sentence element that is not stated explicitly in the next sentence (Ramlan, in Antony, 2012: 373). The omitted element can be a word, phrase, clause or sentence. Conjunction or conjunction is a type of grammatical cohesion that connects one element to another in a discourse. In this case, the elements that are arranged can be in the form of lingual units of words, phrases, clauses, sentences, and others. Nunan (1993: 26) distinguishes four types of conjunctions, namely conflict, addition, time, cause and effect, and show activity.

Furthermore, lexical cohesion in discourse can be classified into six types, namely: 1) repetition (repetition); 2) synonymy (word equivalent); 3) collocation (sanding words); hyponymy (top-down relationship); 5) antonym (opposite the word); and 6) equivalence (comparability) (Sumarlam, 2003: 35). The function of the use of lexical cohesion in a discourse is to make the text have harmony and as a binder so that the text has meaning.

First, repetition or repetition is a lingual unit that can be in the form of sounds, syllables, words, or sentence parts that are considered important to give emphasis in an appropriate context. Gorys Keraf (in Sumarlam, 2003: 35-38) divides the repetition into eight parts which are adjusted to the place of the repeated lingual unit, namely 1) repetition of epizeuksis, ie repetition of words that are concerned in several consecutive times; 2) tautotes repetition, namely repetition of words several times in a construction; 3) anaphora repetition, i.e. repetition of the first word or phrase in a line or sentence next; 4) epistrofa repetition, i.e. repetition of the lingual unit of words / phrases at the end of a line (in poetry) or end of sentence (in prose) respectively; 5) mesodiplosis repetition, i.e. repetition of the lingual unit in the middle of a row or sentence in a row; 6) repetition of epanalepsis, i.e. repetition of the lingual unit, where the last word / phrase from the line or sentence is the repetition of the first word / phrase; and 7) anadiplosis repetition, i.e. repetition of the last word / phrase from the line / sentence becomes the first word / phrase in the next line / sentence.

Second, synonymy or equivalent word can be interpreted as a word or expression whose meaning is more or less the same as another word or expression. Sumarlam (2003: 39) divides synonymy based on the form of lingual units, namely 1) synonymy morpheme (free) with morpheme (bound); 2) word by word; 3) words with phrases or vice versa; 4) phrase by phrase; and 5) clauses / sentences with clauses / sentences. Third, collocation or word 
sanding can be interpreted as a particular association in using a choice of words that tend to be used side by side. The words used are usually in one particular domain.

Fourth, hyponymy is a unit of language such as words, phrases or sentences whose meaning is considered to be part of the other language units which include several elements or lingual units with a hyponym, called hypernim or superordinate. Fifth, antonym is a lingual unit whose meaning is contrary to other lingual units. Sumarlam (2003: 40) explains that antonymy can be called opposition next; 4) epistrofa repetition, i.e. repetition of the lingual unit of words / phrases at the end of a line (in poetry) or end of sentence (in process) respectively; 5) mesodiplosis repetition, i.e. repetition of the lingual unit in the middle of a row or sentence in a row; 6) repetition of epanalepsis, i.e. repetition of the lingual unit, where the last word / phrase from the line or sentence is the repetition of the first word / phrase; and 7) anadiplosis repetition, i.e. repetition of the last word / phrase from the line / sentence becomes the first word / phrase in the next line / sentence.

Second, synonymy or equivalent word can be interpreted as a word or expression whose meaning is more or less the same as another word or expression. Sumarlam (2003: 39) divides synonymy based on the form of lingual units, namely 1) synonymy morpheme (free) with morpheme (bound); 2) word by word; 3) words with phrases or vice versa; 4) phrase by phrase; and 5) clauses / sentences with clauses / sentences. Third, collocation or sanding words can be interpreted as a particular association in using a choice of words that tend to be used side by side. The words used are usually in one particular domain.
Fourth, hyponymy is a unit of language such as words, phrases or sentences whose meaning is considered to be part of the other language units which include several elements or lingual units with a hyponym, called hypernim or superordinate. Fifth, antonym is a lingual unit whose meaning is contrary to other lingual units. Sumarlam (2003: 40) explains that antonymy can be called opposition mean. Furthermore, Sumarlam divides the opposition of meaning into five types, namely a) absolute opposition, namely the absolute contradiction of meaning; b) polar opposition, ie gradual opposition; c) opposition of the relationship, which is a complementary conflict; d) hierarchical opposition, i.e. contradictions that state levels; and e) compound opposition, namely opposition that occurs in several words. Finally, equivalence or equivalence is the relation of equivalence between certain lingual units with other lingual units, such as the affixation process of morphemes which as long as there is an equivalence relationship, for example the meaning relationship between the word buyer, bought, bought, bought, and buyer.

Lexical cohesion and grammatical discourse cohesion are studies that need to be studied in a discourse. This can be understood because both are important factors in communication. The existence of cohesion elements in a discourse allows the discourse to become a unified and coherent discourse. In other words, whole and coherent discourse must summarize lexical cohesion and grammatical cohesion. Each element in the discourse will not have a clear meaning without a relationship with other elements in the unity of the discourse structure (Rustono, 2011: 27). In its dissemination, discourse can be realized through poetry discourse. 
Poetry discourse as a literary genre discourse is a text that puts forward aesthetic elements as well as its semantic meaning. Poetry is the oldest form of literary work (Waluyo, 2010: 3). Poetry is essentially an outpouring of hearts which in this case is expressed by the poet in beautiful writing. A deeper definition was given by Waluyo who stated that poetry is a literary work that expresses the poet's thoughts and feelings imaginatively and is composed by concentrating all the power of language by concentrating physical and mental structures.

In connection with this research, the type of poetry to be studied is a new poem. Waluyo mentioned that poetry only appeared in Indonesia during the New Poet era (2010: 17) and was not bound by lines, rhymes and rhythms. In addition, the style of language used by the author is fickle and further highlights the problems of life in greater depth. One of the authors of a new poem is Afrizal Malna. Afrizal Malna is one of the writers of the 2000s Period. The poet belongs to a contemporary poet, along with Sutardi Calzoum Bachri and other writers. Characteristics of writing Afrizal Malna's poetry are the use of unusual symbolization, logic games, transfer of word functions in sentences, the formation of material personifications, and the use of distinctive synesthesia.

Therefore, researchers feel interested in bringing up one of Afrizal Malna's poems as objects of discourse analysis studies. In this case, the poem to be investigated is the poem "Museum Penghancur Dokumen" by Afrizal Malna, so the purpose of this research is to describe and explain the grammatical cohesion and lexical cohesion in the poem.

\section{RESEARCH METHODS}

This study examines the cohesiveness of discourse in terms of the grammatical and lexical aspects underlying the discourse of poetry, so that the qualitative research type is categorized. The data in this research is written data. The primary data in this study is the poem "Museum Penghancur Dokumen" by Afrizal Malna, while the secondary data are other books that are relevant to this research. Furthermore, the data collection techniques in this study used literature, reading, and note taking techniques through the poem "Museum Penghancur Dokumen" by Afrizal Malna. Data analysis techniques include three components, namely data reduction (summarizing, selecting things that are important), data presentation (presenting simplified data), and drawing conclusions.

\section{RESULTS AND DISCUSSION}

3.1. Grammatical Cohesion in the poem "Museum Penghancur Dokumen" by Afrizal Malna

Based on the research findings, the grammatical cohesion found in the poem "The Museum Penghancur Dokumen" by Afrizal Malna includes reference (reference), impulse (ellipsis), and concatenation (conjunction).

\section{a. Reference (Reference)}

The use of references used by the author are 39 references consisting of 1) person references; 2) demonstrative reference, which consists of demonstrative time and demonstrative place; and 3) comparative reference.

\section{b. Persona Reference}

In persona referencing there are 18 times referencing. As explained earlier that persona reference is realized through personal pronouns which include the first, second, third persona, and each can be a free and bound morpheme (left and right adherent). Sumarlam (2003: 24) 
explains that the lingual unit of me, you, and he / she can be grouped in the singular pronouns I, II, and III of the free form. Then the bound form can include me (in the word my ego, my body), - you (your sad words, your story).

In the poetry data there are the words "I" and "ku" as pronouns persona I. The words "you" and "mu" as pronominal persona II and the word "his" as pronominal persona III.

\section{c. Demonstrative Reference}

Demonstrative references or indicative pronouns found in the poem "Museum Penghancur Dokumen" by Afrizal Malna were used 9 times. Reference to demonstrations as explained previously can be divided into temporal demonstrative pronouns (time) and locational demonstrative pronouns (places). Demonstrative pronouns exist which refer to the present (present) and the past (12 minutes ago, in the past). Demonstrative pronouns place divided into places close to the speaker (here, this), somewhat close to the speaker (situ, that), far from the speaker (there), and pointing the place explicitly (Medan, Solo) (Sumarlam, 2003: 26) . Demonstrative pronouns the place in the poem is close to the speaker (here, this, in), far from speakers (there, that), explicitly designate places (museums, markets).

d. Comparative Reference

The comparative reference contained in the poem "Museum Penghancur Dokumen" by Afrizal Malna is 1 time. Comparative reference or comparison is to compare two things that have similarities or similarities in terms of form ,. In this case, there are several words that are often used to compare, for example, like, like, like, like, the same as, not different from, exactly like, and exactly the same as (Sumarlam, 2003: 27). But in the poem there is only the word "like" which compares prose with travelers.

\section{e. Conjunction}

Conjunction in the poem "Museum Penghancur Dokumen" by Afrizal Malna with the use of conjunctions 11 times. Some examples of the use of conjunctions and the meanings generated in the poem are in the second stanza of the sixth line namely "if so, change your clothes with mine" as a conjunctural conjunction. "I cried, after I killed myself 12 minutes which" as an intracalimat conjunction stated the time and explanation. Santosa, et al. (2010: 23-25) dividing time conjunctions into 1) sequential time at a time; 2) immediate sequential time; c) near simultaneous time; and d) simultaneous interrupted time. In the data there are word conjunctions that are classified as subordinative conjunctions, namely a conjunction that connects two sentence elements (kalusa) whose position is not equivalent (Kridalaksana, in Antony 2012:

373-374)

Table 3.1. Analysis of Grammatical Cohesion Aspects

\begin{tabular}{|c|c|c|c|c|c|}
\hline Poem & \multicolumn{5}{|c|}{ Grammatical Aspects } \\
\hline \multirow{3}{*}{$\begin{array}{l}\text { Poem } \\
\text { "Museu } \\
m \\
\text { pengha } \\
\text { ncur } \\
\text { dokume } \\
n \text { " }\end{array}$} & \multicolumn{3}{|c|}{ Reference } & \multirow{2}{*}{$\begin{array}{l}\text { Absor } \\
\text { ption }\end{array}$} & \multirow{2}{*}{$\begin{array}{l}\text { conjunc } \\
\text { tion }\end{array}$} \\
\hline & $\begin{array}{c}\text { Perso } \\
\text { na }\end{array}$ & $\begin{array}{l}\text { Demon } \\
\text { strative }\end{array}$ & $\begin{array}{c}\text { comp } \\
\text { arativ } \\
\text { e }\end{array}$ & & \\
\hline & 18 & 9 & 1 & & 11 \\
\hline
\end{tabular}

3.2. Lexical cohesion in the poem "The Document Shredder" by Afrizal Malna

a. Repetition

Repetition or repetition in this poem can be found in several words in 
one sentence section. Repetition or repetition of lingual units, whether syllables, words, or sentence parts, is considered important to emphasize in an appropriate context. Words that are repeated like the word "please" (verse 1), are repeated five times and the word "bored" (verses 1 and 2) three times, and the word "grammar" (verses 3 and 2) three times. In the data is an example of tautotes repetition, namely repetition of words several times in a construction (Gorys Keraf, in Sumarlam, 2003: 36).

b. Antonimi

Antonimi or the opposite of the words in the poem "Museum Penghancur Dokumen" by Afrizal Malna can be found in the following lines. "Kalau bosan makan dan an Perkenankan aku memberikan.. cuci telah mencucinya setelah aku mabuk, setelah..."

In the data above, there is a word $\boldsymbol{a} \boldsymbol{k} \boldsymbol{u}$ and $\boldsymbol{n y} \boldsymbol{a}$ which refers to anthony free morpheme with bound morpheme, namely the absolute contradiction of meaning (Sumarlam, 2003: 40).

\section{c. Equivalence}

Equivalence or equivalence between the relationship of one lingual unit with another lingual unit in the discourse of poetry "Museum Penghancur Dokumen" by Afrizal Malna can be seen in verse 1 of array 7 "Menghancurkan dinding-dinding egoku. How" verse 3 array 6 "mengganti tubuhmu menjadi mesin penghancur",. In this there is an equivalence relation of meaning formed from words menghancurkan, dan penghancur. The words are formed from the original form hancur

Table 3.2. Analysis of aspects of lexical \begin{tabular}{|c|c|c|c|c|c|}
\hline Poem & \multicolumn{5}{|c|}{ lexical cohesion } \\
\cline { 2 - 5 } & Repet & Syn & Ant & coll & Equival \\
\hline
\end{tabular}

\begin{tabular}{|l|c|c|c|c|c|}
\hline & ition & $\begin{array}{c}\text { ony } \\
\mathrm{m}\end{array}$ & $\begin{array}{c}\text { ony } \\
\mathrm{m}\end{array}$ & $\begin{array}{c}\text { ocat } \\
\text { ion }\end{array}$ & ence \\
\hline $\begin{array}{l}\text { Puisi } \\
\text { "Museu } \\
\text { mPengh } \\
\text { ancur } \\
\text { dokume } \\
n \text { " }\end{array}$ & 4 & & 1 & & 1 \\
\hline
\end{tabular}

\subsection{Grammatical Cohesion in Poetry "Mantel Hujan Dua Kota" by Afrizal Malna}

Based on research findings, the grammatical cohesion found in poetry "Mantel Hujan Dua Kota" by Afrizal Malna includes references, ellipsis, and conjunctions.

\section{a. Reference}

The use of reference used by the author in poetic discourse "Mantel Hujan Dua Kota" by Afrizal Malna are 25 references consisting of 1) person references; 2) demonstrative reference, consisting of demonstrative time and demonstrative place; and 3) comparative reference.

\section{b. Persona Reference}

In persona referencing there are 14 times referencing. As explained earlier that persona reference is realized through personal pronouns which include the first, second, third persona, and each can be a free and bound morpheme (left and right adherent). Sumarlam (2003: 24) explains that the lingual units of me, you, and he / she can be grouped in the singular pronouns I, II, and III free form. Then the bound form can include $-k u$ (to the word mataku), -mu (words fotomu), and fotomu), (words mantelnya, lubangnya, mempercayainya) which is the right sticky form and at- (on dibakar) which is the left sticky form.

From the lines of poetry "Mantel Hujan Dua Kota" by Afrizal Malna which contains the persona reference $\boldsymbol{a} \boldsymbol{k} \boldsymbol{u}$ which is the first single person pronoun free form. Word $-\boldsymbol{m u}$ which is a personal pronoun both forms bound. 
Then, said $\boldsymbol{i a}$ is a third person singular free form pronouns. Word mataku denotes the first persona singular bound forma pronouns. Finally, there are - nya (pada mantelnya, lubangnya, mempercayainya) which is the third persona pronoun

c. Demonstrative Reference

Demonstrative reference or pointer pronoun contained in the poem "Mantel Hujan Dua Kota" by Afrizal Malna was used 16 times. Reference to demonstrations as explained previously can be divided into temporal demonstrative pronouns (time) and locational demonstrative pronouns (places). Demonstrative pronouns of time There are demonstrative pronouns that refer to present time (kini and sekarang), lampau (kemarin and dulu), will come (besok and yang akan datang) and neutral time (siang, pukul 09.30). Whereas in demonstrative pronouns the place is divided into places that are close to the speaker (sini, ini), rather close to the speaker (situ, itu), far away with speakers (sana), and designate the place explicitly (Medan, Solo) (Sumarlam, 2003:26).

Demonstrative reference to the place as explained above, which is in poetry "Mantel Hujan Dua Kota" by Afrizal Malna i.e. words itu refers to cities that are located far from the author. Word ruang dalam referring to the inner colonial building, said warung kopi referring to the reality of space explicitly contained therein students. "Biarlah aku sampai ke batas tepi ini, untuk jejak yang..." refers to the place being reached (Semarang). Tanah keraton which refers to the relatic space explicitly visited by the author. " Aku telah dua kota dalam perjalanan dua jam," referring to the reality of Semarang and Yogyakarta explicitly in the poem. "biru dan sebelum kelabu dan sebelum di sini" refers to a place of reality close to the author.

Furthermore, the demonstrative reference to time is in poetry "Mantel Hujan Dua Kota" karya Afrizal Malna that is sepanjang malam refers to wearers who celebrate the new year. Then on the data " setelah berhasil menjadi orang sibuk tidak mandi $\mathbf{2}$ hari," Using Excel for agendas, this data includes implicit data. "Aku telah dua kota dalam perjalanan dua jam," This word also refers to relativity that the writer traveled the distance between Yogyakarta and Semarang for two hours. d. Comparative Reference

Comparative references contained in poetry "Mantel Hujan Dua Kota" by Afrizal Malna is 1 time. Comparative reference or comparison is comparing two things that have similarities or similarities in terms of form ,. In this case, there are several words that are often used to compare for example seperti, bagai, bagaikan, laksana, sama dengan, tidak berbeda dengan, persis seperti, dan persis sama dengan (Sumarlam, 2003:27). But in the poem there are only words "seperti" which compares something "6 pagi, dan aku mempercayainya seperti genta yang berbunyi tanpa berbunyi, bayangan gunung sebelum biru dan sebelum kelabu dan sebelum di sini". This compares the city to be addressed with his belief until before dark.

\section{e. Impulsions (Ellipsis)}

Delipation or ellipsis used in this poem is 4 data, i.e. "bangunanbangunan kolonial. Minum persahabatan" there is a meling of the lingual unit of the new year party which is located at the beginning of the sentence or before the word minuman, "kota yang mengapung 45 derajat di atas sejarah" terjadi pelesapan satuan lingual Semarang yang terletak sebelum kata kota,"padat. Dan bir dingin di 
antara janji-janji, the lingual unit is absorbed kesibukan before word dan bir dingin diantara janji-janji. "6 pagi, dan aku mempercayainya seperti genta yang" the lingual unit is absorbed sampai di tujuan before word dan aku mempercayainya...

Table 3.3. Analysis of aspects of lexical cohesion

\begin{tabular}{|c|c|c|c|c|c|}
\hline Poetry & \multicolumn{5}{|c|}{ lexical cohesion } \\
\hline poetry & \multicolumn{3}{|c|}{ Pengacuan } & \multirow{3}{*}{$\begin{array}{l}\text { Abs } \\
\text { orpt } \\
\text { ion }\end{array}$} & \multirow{3}{*}{$\begin{array}{l}\text { conju } \\
\text { ction }\end{array}$} \\
\hline $\begin{array}{l}\text { "Mantel } \\
\text { Hujan } \\
\text { Dua }\end{array}$ & Personal & $\begin{array}{l}\text { Demon } \\
\text { strative }\end{array}$ & $\begin{array}{c}\text { comp } \\
\text { arativ } \\
\mathrm{e}\end{array}$ & & \\
\hline $\begin{array}{l}\text { Kota } \\
\text { "karya } \\
\text { Afrizal } \\
\text { Malna }\end{array}$ & 14 & 13 & 1 & & \\
\hline
\end{tabular}

\section{f. Conjunction}

Conjunction with poetry "Mantel

Hujan Dua Kota" by Afrizal Malna there are 19 data, with the use of conjunctions 23 times. Word conjunction yang classified as a subordinative conjunction, namely a conjunction that connects two sentence elements (kalusa) whose position is not equal (Kridalaksana, in Antony 2012: 373-374). There is a conjunction of consequences, namely conjunction dengan which belongs to the conjunction of consequences that illustrate how to do events. Conjunction untuk which is classified as a conjunction of objective consequences that indicate the purpose of the event in the first clause. Then said dan as an equality conjunction.

3.4. Lexical cohesion in poetry "Mantel Hujan Dua Kota" by Afrizal Malna

a. Repetition

Repetition or repetition in this poem can be found in several words in one sentence section. Repetition or repetition of lingual units, whether syllables, words, or sentence parts, is considered important to emphasize in an appropriate context. The repetition of this poem is in the first stanza, Kata air laut, hujan, sebelum. These words are examples of tautotes repetition, namely repetition of words several times in a construction (Gorys Keraf, in Sumarlam, 2003: 36).

\section{b. Synonym}

Synonym or equivalent words in poetry "Mantel Hujan Dua Kota" by Afrizal Malna contained in one data that is word

$\boldsymbol{i} \boldsymbol{a}$ and $\boldsymbol{n y} \boldsymbol{a}$, contained in the first stanza of arrays 5 and 7. Synonyms intended are classified as synonym morpheme (free) with morpheme (bound) (Sumarlam, 2003: 39). This is seen in free morphemes $\boldsymbol{I a}$ synonymous with bound morpheme -nya.

c. Antonym

Antonyms or opposite words in poetry "Mantel Hujan Dua Kota" by Afrizal Malna can be found in the second stanza, arrays 1 and 2 viz “aku sampai ke batas tepi ini, untuk jejak yang" dan "membuat lubangnya sendiri." Word $\boldsymbol{a} \boldsymbol{k} \boldsymbol{u}$ and $\boldsymbol{n y a} \boldsymbol{a}$ which refers to anthony free morpheme with bound morpheme, namely the absolute contradiction of meaning (Sumarlam, 2003: 40).

\section{d. Collocation}

Collocation or word sanding, that is the use of certain associations with adjoining words, in poetry "Mantel Hujan Dua Kota" by Afrizal Malna namely in the first stanza "Dalam mantelnya, "rokok kretek dan kartu atm" show objects that are often in the pocket. While, "ilmu sastra, ilmu komunikasi, antropologi" shows the majors within the university.

Table 3.4. Analysis of Lexicon aspect

\begin{tabular}{|l|c|c|c|c|c|}
\hline poetry & \multicolumn{5}{|c|}{ Lexicon aspect } \\
\hline $\begin{array}{l}\text { Poetry } \\
\text { "Mantel } \\
\text { Hujan }\end{array}$ & $\begin{array}{c}\text { Rep } \\
\text { etiti } \\
\text { on }\end{array}$ & $\begin{array}{c}\text { Syno } \\
\text { nym }\end{array}$ & $\begin{array}{c}\text { Anto } \\
\text { nym }\end{array}$ & $\begin{array}{c}\text { colloc } \\
\text { ation }\end{array}$ & $\begin{array}{c}\text { Equiv } \\
\text { alenc } \\
\mathrm{e}\end{array}$ \\
\hline
\end{tabular}




\begin{tabular}{|l|l|l|l|l|l|}
\hline $\begin{array}{l}\text { Dua Kota" } \\
\text { karya }\end{array}$ & 3 & 1 & 1 & 2 & 1 \\
Afrizal & & & & & \\
Malna & & & & & \\
\hline
\end{tabular}

e. Equivalence

Equivalence or equivalence between the relationship of one lingual unit with another lingual unit in the discourse of poetry "Mantel Hujan Dua Kota" by Afrizal Malna can be seen in verse 1 array 14 "pegawai negeri. Para arsitek yang membuat desain",verse 2 array 1 "membuatkan lubangnya sendiri", and verse 3 array 15 "ke batas tepi ini. Sebuah kota yang terbuat dari jam". In this there is an equivalence relation of meaning formed from words membuat, membuatkan, terbuat. The words are formed from the original form buat.

3.5. Grammatical Cohesion in poetry "Proposal Politik Untuk Polisi" by Afrizal Malna

Based on research findings, the grammatical cohesion found in poetry "Proposal Politik Untuk Polisi" by Afrizal Malna include reference,ellipsis, and conjunctions.

a. Reference

The use of reference used by the author in poetic discourse "Proposal Politik Untuk Polisi” by Afrizal Malna there are 14 references consisting of 1) person references; 2) demonstrative reference, consisting of demonstrative time and demonstrative place; and 3) comparative reference.

b. Persona Reference

Persona reference used in the poem is pronoun " $a k u$ " in verse I and array I. Word "kau" contained in verse I and array 8. In addition, the word possession " $k u$ " contained in the 2 nd verse of the 5th row.

c. Demonstrative Reference

Demonstrative reference or pointer pronoun contained in the poem
"Proposal Politik Untuk Polisi " by Afrizal Malna used 16 times. Word "di sana" and "di sini", "dalam peti", "di atas", "dari jalan", "dalam panci" showing an object and an uncertain item. This reference is found in verses I and II. 3.6. Comparative Reference

Comparative references contained in poetry "Proposal Politik Untuk Polisi" karya Afrizal Malna is 2 times. Comparative reference or comparison is comparing two things that have similarities or similarities in terms of form ,. In this case, there are several words that are often used to compare for example seperti, bagai, bagaikan, laksana, sama dengan, tidak berbeda dengan, persis seperti, dan persis sama dengan (Sumarlam, 2003:27). "Aku memotret telapak tanganku sendiri, seperti memotret sebuah" (verse I and array II).

a. Conjunction

Conjunction with poetry "Proposal

Politik untuk Polisi" karya Afrizal Malna 24 data, with the use of conjunctions as many as 24 times. Word conjunction yang classified as a subordinative conjunction, namely a conjunction that connects two sentence elements (kalusa) whose position is not equal (Kridalaksana, in Antony 2012: 373374). Conjunction dan as a conjunction of equality and spread almost throughout the temple.

Table 3.5. Analysis of Gramatical Aspect

\begin{tabular}{|l|c|c|c|c|c|}
\hline \multicolumn{1}{|c|}{ Poetry } & \multicolumn{5}{|c|}{ Gramatical Aspect } \\
\hline Poetry & \multicolumn{4}{|c|}{ Reference } & Absor \\
"Proposa \\
\cline { 2 - 6 } $\begin{array}{l}\text { l Politik } \\
\text { Untuk }\end{array}$ & $\begin{array}{c}\text { Perso } \\
\text { nal }\end{array}$ & $\begin{array}{c}\text { Demon } \\
\text { strative }\end{array}$ & $\begin{array}{c}\text { comp } \\
\text { arativ } \\
\text { polisi }\end{array}$ & $\begin{array}{c}\text { unct } \\
\text { ioni }\end{array}$ \\
\cline { 2 - 6 } $\begin{array}{l}\text { P.J.F. } \\
\text { van Heut } \\
\text { sz, }\end{array}$ & 6 & 6 & 2 & 0 & 24 \\
\hline
\end{tabular}

3.7. Lexical cohesion in poetry "Proposal Politik Untuk Polisi" by Afrizal Malna 
a. Repetition

Repetition or repetition in this poem can be found in several words in one sentence section. Repetition or repetition of lingual units, whether syllables, words, or sentence parts, is considered important to emphasize in an appropriate context. The repetition of this poem is in the first stanza, Kata kegagalan dan malam. Kata-kata tersebut adalah contoh repetisi tautotes, yaitu pengulangan kata beberapa kali dalam sebuah konstruksi (Gorys Keraf, dalam Sumarlam, 2003:36).

\section{b. Synonym}

Synonym or equivalent words in poetry "Proposal Politik Untuk Polisi" by Afrizal Malna contained in the two data words $\boldsymbol{a} \boldsymbol{k} \boldsymbol{u}$ dan $\boldsymbol{k} \boldsymbol{u}$, contained in the second stanza of lines 1 and 5. Sinonim yang dimaksudkan tergolong dalam sinonimi morfem (bebas) dengan morfem (terikat) (Sumarlam, 2003:39).

\section{c. Antonym}

Antonymes or opposite words in poetry "Proposal Politik Untuk Polisi" by Afrizal Malna can be found in the fourth stanza, arrays 1 and 2 viz "Kita dan mereka" Word kita and mereka which refers to anthony free morpheme with bound morpheme, namely the absolute contradiction of meaning (Sumarlam, 2003: 40).

\section{d. Collocation}

Collocation or word sanding, that is the use of certain associations with adjoining words, in poetry "Proposal Politik Untuk Polisi” by Afrizal Malna tertawa and tersenyum and pembelian dan penjualan.

\section{e. Equivalence}

Equivalence or equivalence between the relationship of one lingual unit with another lingual unit in the discourse of poetry "Proposal Politik untuk Polisi" by Afrizal Malna can be seen in verses II and III of array I "Aku memotret telapak tanganku sendiri, seperti memotret sebuah..." (II/1),

"Tuan-tuan, bisakah kegagalan dipotret, untuk melihat..." This shows that comparability can be seen from the same basic word even though it is formed into an affix.

Table 3.6. Analysis of Lexicon aspect

\begin{tabular}{|l|c|c|c|c|c|}
\hline \multicolumn{1}{|c|}{ poetry } & \multicolumn{5}{|c|}{ Lexicon aspect } \\
\cline { 2 - 6 } & $\begin{array}{c}\text { Repet } \\
\text { ition }\end{array}$ & $\begin{array}{c}\text { Sinon } \\
\text { imi }\end{array}$ & $\begin{array}{c}\text { Anto } \\
\text { nimi }\end{array}$ & $\begin{array}{c}\text { colloc } \\
\text { ation }\end{array}$ & $\begin{array}{c}\text { Equival } \\
\text { ensi }\end{array}$ \\
\hline $\begin{array}{l}\text { Poetry } \\
\text { "Propos } \\
\text { al Politik }\end{array}$ & 4 & 2 & 2 & 2 & 2 \\
Untuk & & & & & \\
Polisi" & & & & & \\
P.J.F. & & & & & \\
van Heut & & & & & \\
sz, & & & & & \\
\hline
\end{tabular}

\section{CONCLUSION}

4.1. Conclusion

Based on the research findings, it was concluded that the grammatical cohesion used in the collection of poetry "Museum Penghancur Dokumen" by Afrizal Malna found 313 markers which include; 1) referencing 168 markers; 2) absorption of 2 markers; and 3) assembling 143 markers. Furthermore, the use of lexical cohesion used in the discourse of the poem "Document Destruction Museum" by Afrizal Malna was found as many as 93 markers which included; 1) repetition of 39 markers; 2) synonym 11 markers; 3) antonimi 29 markers; 4) collocation of 9 markers; and 5) equivalence of 5 markers. When combined, the total usage of both is 406 markers.

Thus, the use of grammatical cohesion in the collection of poems "Document Shredder" by Afrizal Malna is more dominant than the use of his lexical cohesion. The dominant use of grammatical cohesion is the use of reference (reference) as many as 168 markers from the 406 markers used in the poetry discourse. 


\subsection{Suggestion}

This finding is very important to be understood by researchers in order to add insight into cohesion, especially in poetry discourse, then for subsequent researchers, this research can serve as a basis and reference in conducting similar research or further research in the field of linguistics especially discourse studies.

\section{REFERENCES}

Antony. dkk. 2012. Pemarkah Kohesi Gramatikal pada Kumpulan Cerpen Bintang Kecil di Langit Kelam Karya Jamal T. Suryanata. Jurnal Pendidikan Bahasa dan Sastra Indonesia. Vol. 1 No. 1 September 2012; Seri E 339-425. Universitas Negeri Padang

Nugroho, Rudi A. 2012. Aspek Gramatikal dan Leksikal dalam Naskah Drama Barabah Karya Motinggo Busye: Sebuah Analisis Wacana Sastra. Jurnal

Nunan, David. 1993. Introducing Discourse Analysis. England: Penguin English

Rustono, 2011. Kohesi Leksikal dan Kohesi Gramatikal dalam Karya Ilmiah Siswa Sma Sekota Semarang. Jurnal. Lingua Jurnal Bahasa dan Sastra Volume VII/1 Januari 2011. Universitas Negeri Semarang

Santosa, Riyadi. 2010. Logika Wacana: Analisis Hubungan Konjungtif dengan Pendekatan Linguistik Sistematik Fungsional. Surakarta: UNS Press

Setiawan, Budhi. 2010. Analisis Wacana dan Pembelajaran Bahasa. Salatiga: Widya Sari Press

Sumarlam. dkk. 2003. Teori dan Praktik Analisis Wacana. Surakarta: Pustaka Cakra
Waluyo, Herman J. 2010. Pengkajia $n$ dan Apresiasi Puisi. Salatiga: Widya Sari Press 
